bioRxiv preprint doi: https://doi.org/10.1101/2020.12.14.422622; this version posted December 15, 2020. The copyright holder for this preprint (which was not certified by peer review) is the author/funder, who has granted bioRxiv a license to display the preprint in perpetuity. It is made available under aCC-BY 4.0 International license.

\title{
Development of additional microsatellite primers for the mangrove tree species Avicennia
}

germinans

Hayley Craig ${ }^{1 *}$ Ilka C. Feller ${ }^{2}$, and Jennifer K. Rowntree ${ }^{3}$

${ }^{*}$ Corresponding author

${ }^{1}$ Department of Earth and Environmental Sciences, The University of Manchester, Oxford Road,

Manchester, M13 9PT, United Kingdom. hcraig@hotmail.com.au

${ }^{2}$ Smithsonian Environmental Research Center, Contees Wharf Rd, Edgewater, MD, 21037, USA

${ }^{3}$ Ecology and Environment Research Centre, Department of Natural Sciences, Manchester

Metropolitan University, Chester Street, Manchester, M1 5GD, United Kingdom. 


\section{Abstract}

Objective: The objective of this study was to develop additional microsatellite primers for the mangrove tree species Avicennia germinans that work in multiplex PCR panels to enable cost effective population analyses of this species at a finer scale.

Results: Primer sets were identified from whole genome sequencing data and combined into multiplex PCR panels. Five multiplex reactions containing 20 novel primer sets with trinucleotide repeats were successfully developed. Fifteen of the microsatellite loci were polymorphic in the samples tested, with 1-4 alleles per locus.

\section{Introduction}

North-eastern Florida is currently considered the northern most range limit of mangrove distribution (Cavanaugh et al. 2019) and its mangrove ecosystems are poor in plant species diversity, with only three species found in the state (Spalding 2010). This makes these environments ideal for investigating a range of topics including: range expansion (Kennedy et al. 2017), effects of intraspecific diversity on ecosystem properties (Craig et al. 2020), and frost adaptation (Hayes et al. 2020). Of the three true mangrove tree species found in Florida, Avicennia germinans is the most wide-ranging (Nelson 2010) and several studies have used microsatellite markers to investigate population structure of this species at the regional scale (e.g. Hodel et al. 2016; Kennedy et al. 2020). While microsatellite markers have been developed for A. germinans (Cerón-Souza et al. 2006; Nettel et al. 2005; Mori et al. 2010), they have been designed for use in singleplex PCR reactions of varying cycle conditions. The cost and time constraints of running multiple PCRs have limited the number of markers used in studies to date. To enable researchers to look at finer scale population genetic structure of $A$. germinans, both in Florida and further afield, we have developed novel microsatellite markers using material collected from this region, and combined them into multiplex PCR panels to reduce time and costs needed for analysis. These new markers could be combined with existing markers to boost the total number used in studies and increase the resolution at which inferences can be drawn. 


\section{Methods}

\section{Microsatellite development}

Microsatellite primers were developed following the Griffiths et al. (2016) workflow. Briefly, genomic DNA from one A. germinans individual collected from Pine Island was selected for sequencing using the MiSeq System (Illumina Inc., San Diego, USA) with $2 \times 250$ bp read length to create a paired-end library. Raw data (2 209638 reads) were imported into Palfinder Galaxy, a customised version of Galaxy (Afgan et al. 2016) managed by The University of Manchester's Bioinformatics Core Facility. Reads were filtered and trimmed based on quality using Trimmomatic (Bolger et al. 2014), microsatellites were isolated using Pal_finder (Castoe et al. 2012), primers were designed using Primer3 (Koressaar \& Remm 2007; Untergasser et al. 2012), and primers were then filtered using Pal_filter (Griffiths et al. 2016) and PANDAseq (Masella et al. 2012). Primer design was optimised to work with the Type-it Microsatellite PCR kit (QIAGEN, Hilden, Germany).

Pal_filter identified primers for 143 loci in regions containing microsatellites with tri- or tetranucleotide perfect repeat motifs. We excluded dinucleotide repeats because although they can detect greater genetic variation (Merritt et al. 2015), they are more prone to slipped-strand mispairing (stuttering), which can result in genotyping errors (Zalapa et al. 2012). As only 20 primer sets were identified in the final assembly step of the pipeline with PANDAseq, an additional 10 primers were randomly selected from the filtered primers (without assembly) output for testing. Primers were tested following the methods developed by Culley et al. (2013), adjusted for $5 \mu l$ reactions instead of $10 \mu \mathrm{l}$. In summary, unlabelled and untailed primer pairs were first tested in singleplex PCRs using the Type-it Microsatellite PCR kit to check whether they amplified fragments. All primers were tested in the same conditions to find those that could be combined together into multiplexes. All PCR amplifications were carried out under the following conditions: $95{ }^{\circ} \mathrm{C}$ for $5 \mathrm{~min}$; followed by 28 cycles of $95^{\circ} \mathrm{C}$ for $30 \mathrm{~s}, 60^{\circ} \mathrm{C}$ for $1 \min 30 \mathrm{~s}$ and $72{ }^{\circ} \mathrm{C}$ for $30 \mathrm{~s}$; followed by $30 \mathrm{~min}$ extension at $60^{\circ} \mathrm{C}$. PCR product was examined by $1.5 \%(\mathrm{w} / \mathrm{v})$ agarose $0.5 \times$ TBE buffer ( $45 \mathrm{mM}$ Trisborate, 1mM EDTA) gel electrophoresis with GelGreen stain (Biotium Inc., Fremont, CA, USA). 
Twenty three of the 30 primer sets tested amplified successfully and continued to the second stage of testing; amplifying forward tailed (but unlabelled) primers with reverse primers in singleplex PCR. Twenty of the primer sets amplified successfully and continued to the third stage of testing in singleplex PCRs with a fluorescently labelled tail added. $0.5 \mu$ l of labelled PCR product was mixed

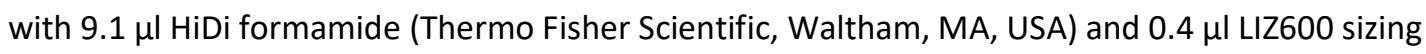
ladder (Applied Biosystems, Foster City, CA, USA) prior to fragment sizing on the ABI3730 (Applied Biosystems, Foster City, CA, USA).

Once the size of the fragments from each locus was known, Multiplex Manager (Holleley \& Geerts 2009) was used to combine loci into suitable PCR multiplexes using three fluorescent labels (6-FAM, HEX and PET). If any primer sets did not successfully amplify in multiplex for microsatellite scoring, multiplex combinations were optimised until all included primer pairs were working. Five multiplex PCR panels comprising 20 primer sets were tested (Table 1). All primer sets in final multiplexes were for trinucleotide repeat motifs.

\section{Multiplex testing}

Initial microsatellite primer testing was conducted on DNA extracted from the leaves of $16 \mathrm{~A}$. germinans individuals from two sites within the Indian River Lagoon system: eight collected from Pine Island Conservation Area, Brevard County, Florida $\left(28.4827^{\circ} \mathrm{N}, 80.7240^{\circ} \mathrm{W}\right)$ and eight from Avalon State Recreation Area on North Hutchinson Island, St Lucie County, Florida $\left(27.5488^{\circ} \mathrm{N}\right.$, $\left.80.3269^{\circ} \mathrm{W}\right)$. Genomic DNA was extracted from $30 \mathrm{mg}$ dried, ground leaf tissue using the Qiagen DNeasy Plant extraction kit as per the manufacturer's protocol. Quality and quantity of DNA extractions were checked using a NanoDrop 1000 spectrophotometer (Thermo Fisher Scientific, Wilmington, DE, USA). Once the multiplex PCR panels of microsatellites had been successfully optimised, final testing was performed on additional samples totalling 30 individuals from each of the two sites.

The microsatellite data were analysed using GeneMapper version 4.1 (Applied Biosystems, Foster City, CA, USA) to separate fragments based on dye colour and size and then to pick peaks for each 
locus. Some manual editing was required of bins due to differences observed in duplicate samples between plates. Binned data was imported into GenAlEx 6.502 (Peakall \& Smouse 2012), to assess numbers of alleles, heterozygosity, and Hardy-Weinberg equilibrium.

\section{Results and Discussion}

Overall, 15 of the 20 primer sets in the multiplex panels were found to be polymorphic within the samples from primer development tests (Tables 1 and 2). We identified 43 total alleles, number of alleles per locus ranged from 1-4, and 13 private alleles were identified. All loci conformed to Hardy-Weinberg equilibrium (HWE) at the Avalon site, but six loci deviated from Hardy-Weinberg equilibrium in the Pine Island samples.

Here, we have successfully developed novel microsatellite markers for the mangrove tree species $A$. germinans that work in multiplex PCR conditions. These could be combined with existing markers from the literature for more in-depth population analyses in areas of potentially low genetic diversity.

\section{Authors' contributions}

$\mathrm{HC}$ and JKR conceived and designed the study. $\mathrm{HC}$ collected the field samples, designed and tested the microsatellite primers, analysed the data, and prepared the manuscript. JKR and ICF supervised the project and provided guidance on the analyses. All authors read and approved the final manuscript.

\section{Acknowledgements}

The study contained in this publication was supported by Natural Environment Research Council (NERC) EAO Doctoral Training Partnership (NE/L002469/1) funding to HC. The authors wish to thank John Paul Kennedy for his assistance in the field and useful insights. Microsatellite fragment sizing was conducted at The University of Manchester Genomic Technologies Core Facility by Paul Fullwood and Fraser Combe. The authors would also like to thank Florida State Parks and the 
Brevard County Parks and Recreation Department Environmentally Endangered Lands Program for access to the sites and permission to collect samples.

\section{References}

Afgan, E., Baker, D., van den Beek, M., Blankenberg, D., Bouvier, D., Čech, M., Chilton, J., Clements, D., Coraor, N., Eberhard, C., Grüning, B., Guerler, A., Hillman-Jackson, J., Von Kuster, G., Rasche, E., Soranzo, N., Turaga, N., Taylor, J., Nekrutenko, A. \& Goecks, J., 2016. The Galaxy platform for accessible, reproducible and collaborative biomedical analyses: 2016 update. Nucleic Acids Research, 44(W1), pp.W3-W10.

Bolger, A.M., Lohse, M. \& Usadel, B., 2014. Trimmomatic: a flexible trimmer for Illumina sequence data. Bioinformatics , 30(15), pp.2114-2120.

Castoe, T.A., Poole, A.W., de Koning, A.P.J., Jones, K.L., Tomback, D.F., Oyler-McCance, S.J., Fike, J.A., Lance, S.L., Streicher, J.W., Smith, E.N. \& Pollock, D.D., 2012. Rapid Microsatellite Identification from Illumina Paired-End Genomic Sequencing in Two Birds and a Snake. PLoS ONE, 7(2), p.e30953.

Cavanaugh, K.C., Dangremond, E.M., Doughty, C.L., Williams, A.P., Parker, J.D., Hayes, M.A., Rodriguez, W. \& Feller, I.C., 2019. Climate-driven regime shifts in a mangrove-salt marsh ecotone over the past 250 years. PNAS, 116 (43), 21602-21608.

Cerón-Souza, I., Rivera-Ocasio, E., Funk, S.M. \& Mcmillan, W.O., 2006. Development of six microsatellite loci for black mangrove (Avicennia germinans). Molecular Ecology Notes, 6(3), pp.692694.

Craig , H., Kennedy, J.P., Devlin, D.J., Bardgett, R.D. \& Rowntree, J.K., 2020. Effects of maternal genotypic identity and genetic diversity of the red mangrove Rhizophora mangle on associated soil bacterial communities: A field-based experiment. Ecology and Evolution, 00:1-11. DOI:

10.1002/ece3.6989. 
Culley, T.M., Stamper, T.I., Stokes, R.L., Brzyski, J.R., Hardiman, N. a., Klooster, M.R. \& Merritt, B.J., 2013. An Efficient Technique for Primer Development and Application that Integrates Fluorescent Labeling and Multiplex PCR. Applications in Plant Sciences, 1(10), pp.1-10.

Francisco, P.M., Mori, G.M., Alves, F.M., Tambarussi, E. V. \& de Souza, A.P., 2018. Population genetic structure, introgression, and hybridization in the genus Rhizophora along the Brazilian coast. Ecology and Evolution, 8(6), pp.3491-3504.

Griffiths, S.M., Fox, G., Briggs, P.J., Donaldson, I.J., Hood, S., Richardson, P., Leaver, G.W., Truelove, N.K. \& Preziosi, R.F., 2016. A Galaxy-based bioinformatics pipeline for optimised, streamlined microsatellite development from Illumina next-generation sequencing data. Conservation Genetics Resources, pp.1-6.

Hayes, M.A., Shor, A.C., Jesse, A., Miller, C., Kennedy, J.P. \& Feller, I., 2020. The role of glycine betaine in range expansions; protecting mangroves against extreme freeze events. Journal of Ecology, 108(1), pp.61-69.

Hodel, R.G.J., de Souza Cortez, M., Soltis, P.S. \& Soltis, D.E., 2016. Comparative phylogeography of black mangroves (Avicennia germinans) and red mangroves (Rhizophora mangle) in Florida: Testing the maritime discontinuity in coastal plants. American Journal of Botany, 103(4), pp.730-739.

Holleley, C.E. \& Geerts, P.G., 2009. Multiplex Manager 1.0: A cross-platform computer program that plans and optimizes multiplex PCR. BioTechniques, 46(7), pp.511-517.

Kennedy, J.P., Garavelli, L., Truelove, N.K., Devlin, D.J., Box, S.J., Chérubin, L.M. \& Feller, I.C., 2017. Contrasting genetic effects of red mangrove (Rhizophora mangle L.) range expansion along West and East Florida. Journal of Biogeography, 44(2), pp.335-347.

Kennedy, J.P., Preziosi, R.F., Rowntree, J.K. \& Feller, I.C., 2020. Is the central-marginal hypothesis a general rule? Evidence from three distributions of an expanding mangrove species, Avicennia germinans (L.) L. Molecular Ecology, 29(4), pp.704-719. 
Koressaar, T. \& Remm, M., 2007. Enhancements and modifications of primer design program

Primer3. Bioinformatics , 23(10), pp.1289-1291.

Masella, A.P., Bartram, A.K., Truszkowski, J.M., Brown, D.G. \& Neufeld, J.D., 2012. PANDAseq:

Paired-end assembler for illumina sequences. BMC Bioinformatics.

Merritt, B.J., Culley, T.M., Avanesyan, A., Stokes, R. \& Brzyski, J., 2015. An Empirical Review:

Characteristics of Plant Microsatellite Markers that Confer Higher Levels of Genetic Variation.

Applications in Plant Sciences, 3(8), p.1500025.

Mori, G.M., Zucchi, M.I., Sampaio, I. \& Souza, A.P., 2010. Microsatellites for the mangrove tree

Avicennia germinans (acanthaceae): Tools for hybridization and mating system studies. American Journal of Botany, 97(9), pp.79-81.

Nelson, G., 2010. The Trees of Florida: A Reference and Field Guide. Pineapple Press Inc, Sarasota, Florida, pp. 73-76.

Nettel, A., Rafii, F. \& Dodd, R.S., 2005. Characterization of microsatellite markers for the mangrove tree Avicennia germinans L. (Avicenniaceae). Molecular Ecology Notes, 5(1), pp.103-105.

Peakall, R. \& Smouse, P.E., 2012. GenAlEx 6.5: genetic analysis in Excel. Population genetic software for teaching and research-an update. Bioinformatics, 28(19), pp.2537-2539.

Ribeiro, D.O., Vinson, C.C., Nascimento, D.S.S., Mehlig, U., Menezes, M.P.M., Sampaio, I. \& Silva, M.B., 2013. Isolation of microsatellite markers for the red mangrove, Rhizophora mangle

(Rhizophoraceae). Applications in plant sciences, 1(9), p.1300003.

Rosero-Galindo, C., Gaitan-Solis, E., Cárdenas-Henao, H., Tohme, J. \& Toro-Perea, N., 2002.

Polymorphic microsatellites in a mangrove species, Rhizophora mangle L. (Rhizophoraceae). Molecular Ecology Notes, 2, pp.281-283. 
Takayama, K., Tamura, M., Tateishi, Y. \& Kajita, T., 2008. Isolation and characterization of

microsatellite loci in the red mangrove Rhizophora mangle (Rhizophoraceae) and its related species.

Conservation Genetics, 9(5), pp.1323-1325.

Untergasser, A., Cutcutache, I., Koressaar, T., Ye, J., Faircloth, B.C., Remm, M. \& Rozen, S.G., 2012.

Primer3-new capabilities and interfaces. Nucleic Acids Research , 40(15), pp.e115-e115.

Xin, Z. \& Chen, J., 2012. A high throughput DNA extraction method with high yield and quality. Plant methods, 8(1), p.26. Available at: http://plantmethods.biomedcentral.com/articles/10.1186/1746-

4811-8-26.

Zalapa, J.E., Cuevas, H., Zhu, H., Steffan, S., Senalik, D., Zeldin, E., McCown, B., Harbut, R. \& Simon, P., 2012. Using next-generation sequencing approaches to isolate simple sequence repeat (SSR) loci in the plant sciences. American Journal of Botany, 99(2), pp.193-208. 
Table 1. Characteristics of five microsatellite multiplex panels including 20 novel primer sets developed for Avicennia germinans

\begin{tabular}{|c|c|c|c|c|c|c|c|}
\hline Locus & Primer sequences (5'-3') & $\begin{array}{c}\text { Repeat } \\
\text { motif }\end{array}$ & $\begin{array}{l}\text { Approx size } \\
\text { (bp) }\end{array}$ & Mulitplex & $\begin{array}{c}\text { Flourescent } \\
\text { label }\end{array}$ & 5' F-tail ${ }^{1}$ & 5' F-tail sequence \\
\hline AvGm17 & $\begin{array}{l}\text { F: TACCCGAAAAGGGTTGAGAAAAGGG } \\
\text { R: CCGACAAGAATTCTAACGCCAATGC }\end{array}$ & ATT & $182-185$ & 1 & 6FAM & M13(-21) & TGTAAAACGACGGCCAGT \\
\hline AvGm19 & $\begin{array}{l}\text { F: CCATGCAAGATGAGTCCTCATAGCC } \\
\text { R: TCGCTACTTTACGCAATTTGATTGG }\end{array}$ & ATT & $373-376$ & 1 & PET & M13 mod B & CACTGCTTAGAGCGATGC \\
\hline AvGm23 & $\begin{array}{l}\text { F: TGTGATTAGTTCCCTCATTCTTCTACTCC } \\
\text { R: TTTTGGACAAGGTTTGCATGATTGC }\end{array}$ & TTC & 403 & 1 & 6FAM & M13(-21) & TGTAAAACGACGGCCAGT \\
\hline AvGm29 & $\begin{array}{l}\text { F: CTCCCTTACGTACGCTGATTTTTGGC } \\
\text { R: TGAGCCCTGATTATGATGAAATGGG }\end{array}$ & TGC & $264-278$ & 1 & 6FAM & M13(-21) & TGTAAAACGACGGCCAGT \\
\hline AvGm30 & $\begin{array}{l}\text { F: AAAGACGAAGTATGGGGACATCTGG } \\
\text { R: GGAAATAAATCAGCCACCCTTAAAAGC }\end{array}$ & ATC & $419-422$ & 1 & HEX & T7term & CTAGTTATTGCTCAGCGGT \\
\hline AvGm02 & $\begin{array}{l}\text { F: CCTTCCGTTTTCTCGTTCCTCTGC } \\
\text { R: CGTGGGAGTGCAACTTTTATGAGTCC }\end{array}$ & TTC & $330-336$ & 2 & HEX & T7term & CTAGTTATTGCTCAGCGGT \\
\hline AvGm14 & $\begin{array}{l}\text { F: CACACCCATCACTGAACTATTAACTGACC } \\
\text { R: ATGGATTCTACACAAATGAGGTTGG }\end{array}$ & ATT & $164-167$ & 2 & 6FAM & M13(-21) & TGTAAAACGACGGCCAGT \\
\hline AvGm15 & $\begin{array}{l}\text { F: TGGTTACACATTGTTTTGTGGTTTGGC } \\
\text { R: AGGTTCCGTGTTTCATTCTCCAACG }\end{array}$ & ATT & $240-243$ & 2 & 6FAM & M13(-21) & TGTAAAACGACGGCCAGT \\
\hline AvGm18 & $\begin{array}{l}\text { F: ATTATGTCTGGGTTCACCAGTTGCC } \\
\text { R: CCATACACGAGGTCACCAAATCAGC }\end{array}$ & TTC & $319-340$ & 2 & 6FAM & M13(-21) & TGTAAAACGACGGCCAGT \\
\hline AvGm20 & $\begin{array}{l}\text { F: ATTCCAACAAAACCAGTCCCACACC } \\
\text { R: CGCTCAAATTTATGGCTGATTCTGG }\end{array}$ & ATT & 309 & 2 & PET & M13 mod B & CACTGCTTAGAGCGATGC \\
\hline AvGm05 & $\begin{array}{l}\text { F: GCCCTGTTTAGATAGGGGTCACAGG } \\
\text { R: TGACTTTACATTGTGGGGATCTGTTGC }\end{array}$ & TTC & $380-389$ & 3 & PET & M13 $\bmod B$ & CACTGCTTAGAGCGATGC \\
\hline AvGm12 & $\begin{array}{l}\text { F: TGCACCCTTTAGTCCAGTCATTTGG } \\
\text { R: TCCTAGTTTCACTCCACCAATGTCG }\end{array}$ & ATT & 312 & 3 & HEX & T7term & CTAGTTATTGCTCAGCGGT \\
\hline AvGm25 & $\begin{array}{l}\text { F: CCACAGTTCTTCTCCAGCCCTTTCC } \\
\text { R: TCGTTCTTCTTCGAGATTCTGATGG }\end{array}$ & ACC & $318-330$ & 3 & 6FAM & M13(-21) & TGTAAAACGACGGCCAGT \\
\hline AvGm06 & $\begin{array}{l}\text { F: GACAATTTGCCCCGTTTGTAGATCC } \\
\text { R: AGCATGAGTCCGGATGACATTACCG }\end{array}$ & ACC & $198-201$ & 4 & 6FAM & M13(-21) & TGTAAAACGACGGCCAGT \\
\hline AvGm07 & $\begin{array}{l}\text { F: TCGTAGGAAGCAAATGCATAAGTCG } \\
\text { R: ATGAGCTATACGCTTGAGGATTCCC }\end{array}$ & ATT & $312-339$ & 4 & HEX & T7term & CTAGTTATTGCTCAGCGGT \\
\hline AvGm08 & $\begin{array}{l}\text { F: GCCTTGAGTTTCGAAGGATACTTGCC } \\
\text { R: TGACAAGAAAGGCTACATCAAATGGC }\end{array}$ & ATT & $274-291$ & 4 & 6FAM & M13(-21) & TGTAAAACGACGGCCAGT \\
\hline AvGm26 & $\begin{array}{l}\text { F: GCAAACTTTCCTTTTGCAGATTTGGG } \\
\text { R: AATCGACAGACGGGTTGTGATGTGG }\end{array}$ & TCG & 291 & 4 & PET & M13 mod B & CACTGCTTAGAGCGATGC \\
\hline AvGm04 & $\begin{array}{l}\text { F: ACACTGCAATTTTGTTGGTCATAGG } \\
\text { R: CCCCAAATTTTCTACTCATTAGACC }\end{array}$ & ATC & $374-388$ & 5 & PET & M13 $\bmod B$ & CACTGCTTAGAGCGATGC \\
\hline AvGm16 & $\begin{array}{l}\text { F: GTGCAGAATTCCACCATTTGTCACG } \\
\text { R: GAGAAGTGTGGCGACCTTTTCATCG }\end{array}$ & TTC & $316-328$ & 5 & HEX & T7term & CTAGTTATTGCTCAGCGGT \\
\hline AvGm24 & $\begin{array}{l}\text { F: GGGGCCTAGTTTTCTCTCTTCCC } \\
\text { R: AACCCTAGGTGAGGCCCATTATTGC }\end{array}$ & ATT & 273 & 5 & 6FAM & M13(-21) & TGTAAAACGACGGCCAGT \\
\hline
\end{tabular}

${ }^{1}$ Culley et al. 2013 F: GGGGCCTAGTTTTCTCTCTTCCC
R: AACCCTAGGTGAGGCCCATTATTGC 
bioRxiv preprint doi: https://doi.org/10.1101/2020.12.14.422622; this version posted December $15,2020$. The copyright holder for this preprint (which was not certified by peer review) is the author/funder, who has granted bioRxiv a license to display the preprint in perpetuity. It is made available under aCC-BY 4.0 International license.

Table 2. Genetic diversity of 20 microsatellites developed for Avicennia germinans

\begin{tabular}{ccccccc}
\hline & \multicolumn{3}{c}{ Pine Island, FL $(\mathbf{n}=\mathbf{3 0})$} & \multicolumn{3}{c}{ Avalon, FL (n= 30) } \\
\hline Locus & $\mathrm{A}$ & $\mathrm{H}_{\mathrm{o}}$ & $\mathrm{H}_{\mathrm{e}}$ & $\mathrm{A}$ & $\mathrm{H}_{\mathrm{o}}$ & $\mathrm{H}_{\mathrm{e}}$ \\
\hline AvGm02 & 2 & 0.033 & 0.033 & 3 & 0.367 & 0.455 \\
\hline AvGm04 & 2 & 0.034 & 0.034 & 2 & 0.067 & 0.064 \\
\hline AvGm05 & 3 & 0.233 & 0.383 & 3 & 0.500 & 0.546 \\
\hline AvGm06 & 2 & $0.000^{*}$ & 0.069 & 2 & 0.267 & 0.320 \\
\hline AvGm07 & 2 & $0.179 *$ & 0.484 & 3 & 0.367 & 0.415 \\
\hline AvGm08 & 2 & 0.107 & 0.101 & 2 & 0.133 & 0.180 \\
\hline AvGm12 & 1 & 0.000 & 0.000 & 1 & 0.000 & 0.000 \\
\hline AvGm14 & 1 & 0.000 & 0.000 & 2 & 0.233 & 0.206 \\
\hline AvGm15 & 2 & 0.067 & 0.064 & 1 & 0.000 & 0.000 \\
\hline AvGm16 & 2 & $0.034^{*}$ & 0.098 & 3 & 0.333 & 0.315 \\
\hline AvGm17 & 1 & 0.000 & 0.000 & 2 & 0.067 & 0.064 \\
\hline AvGm18 & 2 & $0.133^{*}$ & 0.278 & 4 & 0.667 & 0.564 \\
\hline AvGm19 & 2 & $0.167 *$ & 0.299 & 2 & 0.467 & 0.500 \\
\hline AvGm20 & 1 & 0.000 & 0.000 & 1 & 0.000 & 0.000 \\
\hline AvGm23 & 1 & 0.000 & 0.000 & 1 & 0.000 & 0.000 \\
\hline AvGm24 & 1 & 0.000 & 0.000 & 1 & 0.000 & 0.000 \\
\hline AvGm25 & 1 & 0.000 & 0.000 & 2 & 0.033 & 0.033 \\
\hline AvGm26 & 1 & 0.000 & 0.000 & 1 & 0.000 & 0.000 \\
\hline AvGm29 & 2 & $0.033^{*}$ & 0.095 & 3 & 0.467 & 0.413 \\
\hline AvGm30 & 1 & 0.000 & 0.000 & 2 & 0.033 & 0.033 \\
\hline
\end{tabular}

Note: $\mathrm{A}=$ number of alleles; $\mathrm{He}=$ expected heterozygosity; $\mathrm{Ho}=$ observed heterozygosity; $\mathrm{n}=$ number of individuals sampled

* Significant deviation from Hardy-Weinberg equilibrium $(p<0.05)$ 